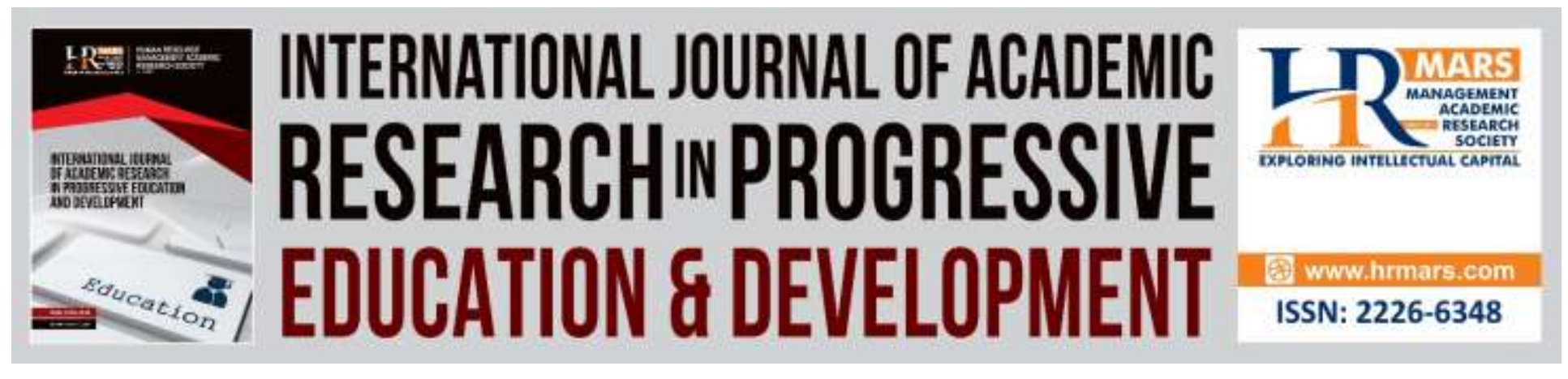

\title{
Systematic Review: Approaches in Teaching Writing Skill in ESL Classrooms
}

\author{
Melanie Selvaraj \& Azlina Abdul Aziz
}

To Link this Article: http://dx.doi.org/10.6007/IJARPED/v8-i4/6564

DOI:10.6007/IJARPED/v8-i4/6564

Received: 12 October 2019, Revised: 27 October 2019, Accepted: 11 November 2019

Published Online: 29 November 2019

In-Text Citation: (Selvaraj, \& Aziz, 2019)

To Cite this Article: Selvaraj, M., \& Aziz, A. A. (2019). Systematic Review: Approaches in Teaching Writing Skill in ESL Classrooms. International Journal of Academic Research in Progressive Education and Development, 8(4), 450-473.

Copyright: (C) 2019 The Author(s)

Published by Human Resource Management Academic Research Society (www.hrmars.com)

This article is published under the Creative Commons Attribution (CC BY 4.0) license. Anyone may reproduce, distribute, translate and create derivative works of this article (for both commercial and non-commercial purposes), subject to full attribution to the original publication and authors. The full terms of this license may be seen at: http://creativecommons.org/licences/by/4.0/legalcode

Vol. 8(4) 2019, Pg. 450 - 473

http://hrmars.com/index.php/pages/detail/IJARPED

JOURNAL HOMEPAGE

Full Terms \& Conditions of access and use can be found at http://hrmars.com/index.php/pages/detail/publication-ethics 


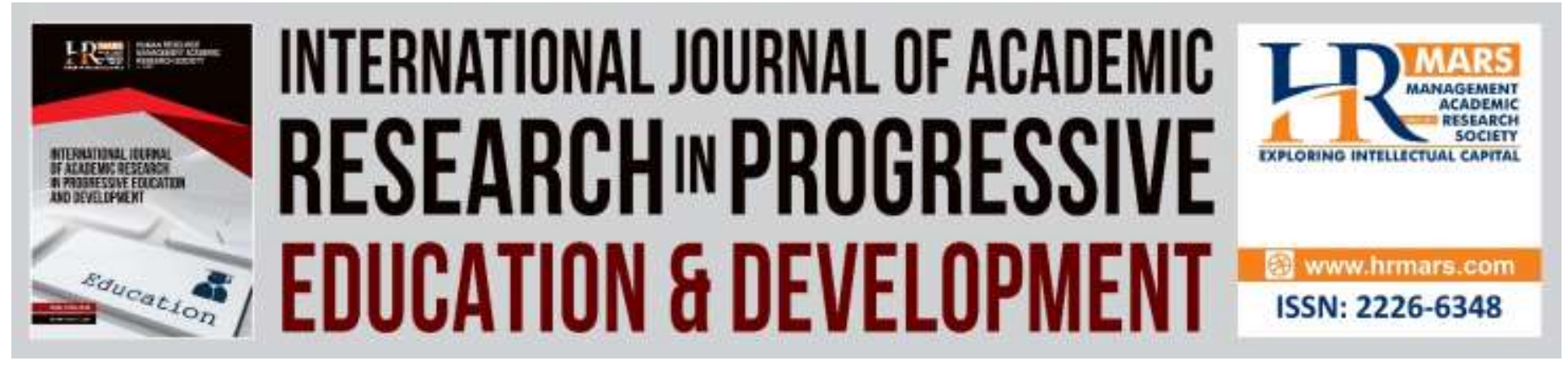

\title{
Systematic Review: Approaches in Teaching Writing Skill in ESL Classrooms
}

\author{
Melanie Selvaraj \& Azlina Abdul Aziz \\ Faculty of Education, Universiti Kebangsaan Malaysia \\ Email: meljude5050@gmail.com, azlina1@ukm.edu.my
}

\begin{abstract}
This paper presents an analysis of a systematic review based on the past studies published on writing approaches employed in ESL classrooms. The studies reviewed are from the year 2000 to 2019 with the total number of eighteen studies. The key aims of this systematic review is to show an empirical information formulation discovered through multiple methods in past scholarly research on writing in ESL classrooms. In this systematic study, there are two study questions to be addressed: i) What teaching methods should ESL students use to enhance writing abilities for learners? ii) How should the defined writing strategy be scheduled so that it can be efficiently applied in the ESL schools? The findings of the reviews showed that process, genre, process genre, process product and product-based approaches are employed in ESL classrooms. Process approach was mostly employed in ESL teaching of writing in secondary and tertiary level. Results also indicated that scaffolding cooperative learning and teacher and peer feedback help to improve ESL students' writing.

Keywords: Writing Approaches, Writing, ESL Classrooms, Process Approach, Teaching Writing Theories

\section{Introduction}

English is a language widely spoken around the globe. About 1,121 billion people regardless of natives or non-natives speak English (World Population Review 2019). It is a language that bridge people in different sectors. English is language of business, education and communication, and even seen as an official language and used in documenting. Second language learning differs from first language acquisition. To meet these requirements there were various theories and hypotheses found and experimented to facilitate educators to impart the knowledge of second language. In addition, various researches di multiple disciplines, such as linguistics, psycholinguistics, psychology and education were carried out to enable students to learn second language. Listening, talking, reading and writing are the primary four language abilities taught to these learners. "Writing is the most challenging skills to be learnt and to be taught in ESL classroom" (Jusun and Md Yunus 2018, p.470). Writing skills is a vital skill that to be mastered by all the students in ESL classrooms as it has its various purposes. It goes beyond the school scope.
\end{abstract}


Vol. 8, No. 4, 2019, E-ISSN: 2226-6348 @ 2019 HRMARS

\section{The Importance of Writing}

Mastering writing skills is important due to its need in almost all the professions which need documentation, especially in this era. It is necessary to enter any modern workplace with good writing skills. According to Zhu (2004), business world requires and expect potential employers with good writing skills and they are seen as the clients of corporate world. Therefore, it is vital to equip oneself with good writing skills to get appointed and to disclosed to more job opportunities. In other words, employee with good writing skills are seen as "hot commodities" Other than that, it is one of the most serious skill to the acquired in tertiary education. Academic writing in tertiary is not just words but meaningful communication. Zhu (2004) added that academic writing includes understanding of distinctive procedures of ideas and interaction which needs basic or general writing abilities as a foundation. Besides that, writing promotes creativity, imagination, and understanding. Writing is a thinking process which involves brain process, in order to organise ideas to write, writers need to imagine and be creative in putting their thoughts in words. Therefore, it is compulsory to incorporate teaching of writing skills in primary schools as it is an important skill in communication in this globalised world (Hyland, 2015). Due to its importance, many countries have made English to be learnt in school as a second language including Malaysia. In Malaysia, students learn English in all level of education starting from preschool to varsity level. In second language learning, learners are identified as second language learners or ESL learners. There are various methods and strategies used to suit the ESL learners to master the writing skills.

\section{Writing Issues among ESL Writers}

Writing is not easy as it "stimulates thinking, compels students to concentrate and organized their ideas, and cultivates their ability to summarize, analyse, and criticize" (Maghsoudi and Haririan 2013, p.60). Bases on previous literature, the biggest challenge is lack of proficiency in English language among ESL students in order to complete writing task assigned. Thus, students need vocabulary, grammar, and ability to structure good sentences is a requirement to compose a writing. Besides that, students feel lost and tough to compose in English since writing requires to use many cognitive and linguistic approaches that students are unsure about. Generating and organizing the ideas is seen as major problem for students who has some linguistic competency in English. They struggle to produce a good writing pieces due to lack of knowledge in generating and organizing ideas and to present their writing with good coherence. Another common issue in writing among ESL students is students are "lack of certain skill such as proper use of grammar, conventions, punctuation, capitalization, and spelling" (Ghabool et al. 2012, p.130; Ramasamy \& Abdul Aziz, 2018, p.2266). Furthermore, according to Normazidah, Lie and Hazita (2012, p.41) "all ESL students face more complicated problems, which may be either cultural or linguistic ones". In line with this, students lose their interest in writing and gradually demotivates the students to write. In contrary, some studies say lack of teachers' pedagogical knowledge in writing and failure of choosing the right strategy to teach writing is another contributing factor for producing incompetent writers among ESL students (Md Yunus and Chan, 2016). These reasons make teaching and learning writing daunting for ESL educators.

Regardless of all the problems, writing skills in Malaysia is prioritised in the education system besides the verbal communication skills. As formulated in Malaysian education Blueprint (2013- 
2025), students need to be proficient in both Bahasa Malaysia and English covering all the language aspects. Yet, after four years of implementing the blueprint, report shows, there is a "decrease in the percentage of passing for SPM English paper, from 79.4 per cent in 2016 to 79.1 per cent in 2017" and for English Writing paper in UPSR examination, the percentage of passing dropped from 77.0 per cent in 2016 to 73.6 per cent in 2017" (Aziz, 2018 para. 15). Teachers, researches do employ many strategies to teaching writing skills to ESL learns, yet the results are frustrating. One important area needed to be reviewed are the approaches employed by teachers in teaching writing. To see the efficacy of these approaches in developing students writing skills in ESL classrooms, an analysis of approaches used in ESL classrooms is required. The main goal of this systematic review is to demonstrate a formulation of empirical data found via various approaches in previous academic studies on the teaching of writing in ESL classrooms. This is to create opportunity to researchers and teachers to formulate interventions and identify the suitable approaches to cater the students' needs and conduct researches in depth in this area.

\section{Literature Review}

\section{Theories of Teaching Writing}

Teaching and learning writing in ESL classrooms are demanding. Researchers develop various theories to assist the learners and teachers because in ESL students have to cope with language proficiency and the process of writing. Theories are crucial for the teachers to know and understand the theories in teaching writing because it will allow the teachers "to implement research-based practices better" (Wright et al. 2015, para 4). Hodges (2017) pointed out four focal theories in teaching writing.

\section{a) Cognitive Process theory of Writing}

Writing is a thinking process. To write, a writer needs to use the mental process such as brainstorming, planning and organizing and it needs creativity. Therefore, cognitive wring process aims to teach students to use mental processing in producing a piece of writing. It is a popular than other writing theories as it has many benefits. This theory was introduced by Flower and Hayes (1981, p.366) “through observations of students' writing and made effort to "introduce theory of cognitive processes involved in composing and to lay groundwork for more detailed study of thinking processes in writing". The four elements highlighted by Flower and Hayes in this theory are "Writers have to go through a process of thinking before writing, a higher-order organizational structure takes place during these procedures, composing involves setting objectives, and authors generate macro and micro objectives to finish the writing task (Flower \& Hayes 1981, p.366). In short it focuses exclusively on the mental writing process.

\section{b) Sociocultural theory of Writing}

Sociocultural theory of writing was coined by Vygotsky which giving importance to motivation, affect, and social influences as components of writing (Hodges 2017). In other words, it explains human learning as a social process and how human intelligence originates in society or culture. Another key point in this theory is socialising or interaction 
is crucial in developing the mental action or process to acquire knowledge. Vygotsky introduced Zone of Proximal Development (ZPD) which explains that students need help and socializing to develop themselves (Vygotsky 1978). Therefore in a ESL writing classrooms, students need collaboration with peers and scaffolding from the teachers as well as peers.

\section{c) Social cognitive theory and self-efficacy in writing}

Social cognitive theory in writing refers to how cognitive, behavioural, personal, and environmental factors interact to determine motivation and behaviour (Bandura 1993). This theory emphasizes in 3 main elements which are observational learning, imitation and modelling. On the other hand, self-efficacy refers to writer's belief in accomplishing a writing task given and able to accept any challenges. This theory explains that, students always developed their perception by looking at past production. Thus, they will choose a task where they have high self-efficacy and evade task with low efficacy. (Bandura 2001). Four goal generalization keys pointed out are self-observation, self-evaluation, self-reaction and self-efficacy. Therefore, in a writing classroom students' cognitive ability and self-belief that is to meet challenges assists in writing instructions

\section{d) Ecological Theory}

Ecological theory was proposed by Cooper (1986, p.368) described it as "an ecology of writing encompasses much more than the individual writer and her immediate context. The students in the writing class interact with one another to create systems that means all the students or the product of writing both regulate and they are regulated by other students' writing in their own environment. One of the significant characteristics of this theory is all the characteristics of any individual writer or piece of writing both determine and are determined by the characteristics of all the other writers and writings in the systems. An important characteristic of ecological systems is that they are fundamentally flexible. Although the structures and contents may be defined at a particular time, they are continually evolving in actual time. The limitation of this theory is that it changes over longer periods of time.

\section{Definitions of Teaching Approaches}

Students in ESL classrooms come from various background and proficiency level due to many factors, one of it is exposure to target language. It may vary based on their location, urban or rural, family background or and in certain situations, students have mother tongue and first language before acquiring the third language. It is vital for ESL teachers to design a very systematic and scrupulous plan for each lesson conducted to engage students then achieve successful learning. Hence, besides methods and techniques, approaches matched to their needs of the students is essential. "Approaches represents and interaction between the learner and the situation of learning with strategies serving as negotiation link leading to as task outcome" (Lavelle and Zuercher 2001, p.375).Meanwhile (Richard and Rodgers 1986, p.204) defined "approach as a set of correlative assumptions dealing with the nature of language teaching and 
learning which is the subject matter need to be taught". In other words, it is a set of ideologies, principles or thoughts about the nature of learning which is decoded in the classroom setting.

\section{Definition of Writing Approaches}

Teaching writing needs various approaches blended with strategies. Writing approach "describe the relationship between the beliefs that writers have about writing and the patterns of writing strategies that they employ". (Lavelle and Bushrow 2007, p.808). The concept of approach therefore reflects an extensive view reflecting on the connection of beliefs regarding writing to methods used by authors, which in turn affects the performance of writing results. In short, writing approaches are the ideas, rules and ethics related to writing process which applied in the classrooms particularly in the teaching writing.

\section{Importance of Writing Approaches}

Writing approaches are essential in every writing lesson. ESL teachers should determine the approach need to be applied in one particular lesson for a few reasons. Identifying the correct approach in a writing classroom is crucial to see an effective outcome. Choosing a non-ideal approach will simply make the lessons daunting to the ESL learners and cause disappointment to the teachers after so much of handwork put in the planning and teaching. In other words, it will demotivate the teachers as well as the students. Next, adapting an appropriate approach in the classroom is important depending on the goal set by the teacher. For instance, beginners with very limited proficiency should be exposed to product-based approach as they need model or examples to begin their writing journey. Without an approach, the writing classroom will move in multiple directions thus the goal set for the particular lesson will not be achievable. Hence, writing approaches are important to meet the goals of the writing (Scott 1996). Furthermore, implying different types of approaches, enables students exposed to various types of methods. This will give opportunity to students to identify and use the correct approach in future writing based on their writing purpose. Students who are aware of the approaches produce a quality piece of writing.

\section{Approaches to Teaching Writing in ESL Classrooms}

Writing approaches to first language users differs from the second language learners. Researches had formulated many theories and approaches to cater to ESL learners writing needs. These writing approaches has gone through a lot of changes over the years to enable the second language learners to become a good writer. (Fujida 2006). A few approaches identified by practitioners for ESL learners they are such as product, process, genre approach and process genre approach. (Md.Kamrul Hasan \& Mohd Moniruzzaman 2014).

\section{Product based Approaches}

Product based approach denotes a writing process which aims to see the end product. Regularly, students imitate a model text to produce one. In other words, students mimic a model composition provided by the teachers. For instance, in the writing classrooms, teachers provide examples or model composition for the students and based on the models, students produce a similar composition. Steel (2004) reported, in order to apply this approach in the ESL writing 
classroom there are four steps to adhere;1) students need to read the model composition and take note on the distinctive features of a composition which are organization of ideas, the use of language and mechanics of writing. 2) students perform controlled practices to exercise the elements outlined in the model text.3) Students attempt to mimic the model essay by organizing a collection of pre-set thoughts to suit the model. 4) Students perform the task by using their skills, sentence structures and various level of vocabulary in order to compose the anticipated composition. Some of the advantages of this approach are students start learning how to use particular pattern-product methods in writing composition systematically, especially in writing narrative descriptive and persuasive essays. In addition, students learn to correct vocabulary and various sentence patterns for these text types and improve students' grammatical awareness (Tangpermpoon 2008). Product based approach lost its popularity as it has no concern over the process of the writing but the grammar structure and syntax. It demotivates the students when accuracy in mimicking is focused rather than students' creativity

\section{Process based Approach}

On the other hand, process-based approach gives great importance to the process of getting the end product. There are four processes involved in the writing process; planning, drafting, revising and editing. Kroll (2001, p.221) "explains drafting and receiving feedback on their drafts, be it from peers and/or from the teacher, followed by revision of their evolving texts is one of the crucial steps in the process-based approach". Adopting this approach enable writers to move back and forth to improve their writing. It also promotes creativity when the writers create their own composition. Thus, it is seen as a dynamic approach as recursive process takes place. Process approach is popular due to its benefits. Students can enhance their writing abilities in the classroom as scaffolding occurs. Other than that, feedback is given by teachers and peer, so it gives opportunity for students to become a better writer. According to Maarof et al. $(2011$, p.30) "teacher feedback is regarded as a main requirement for improvement in students' essay writing". In addition, it stresses on thinking process, this will promote creativity. Despite all the advantages, process-based approach has it disadvantages, it consumes a lot of time, focuses on the process instead of structures and grammar.

\section{Genre based Approach}

In contrast, genre approach looks "writing as pre-dominantly linguistic but, emphasize that writing varies with the social context in which it is produced producing texts based on social context" (Badger and White 2000, p.155). Genre based approach give importance to various types of writing and text types and intertwined with social needs. It has some advantages as such as students learns variety of sentence structures for different text types. "The objective of this approach is knowledge and certain genre and the communicative reason which will enable writers communicate with the community" (Tangpermpoon 2008, p.6). There are some advantages of this approach are it exposes students to different types of text types or genre. "Learners should be exposed to many examples of the same genre to develop their ability to write a particular genre" (Elashri 2013, p.7). In addition, genre-based approach "concerned with teaching learners how to use language patterns to accomplish coherent, purposeful prose writing" as every writing has its purposes to the readers (Tuan 2011, p.123). Other than that, 
genre approach is suitable for beginners as model text is given to assist learning, this will reduce the anxiety among the learners. Above all, it scaffolds writing. Some limitations of this approach are students lack in knowledge of language structure and grammar to reach the target audience and learners basically focus on the product rather than the process and it underestimates the student's ability.

\section{Process Genre-based Approach}

Consequently, process genre-based approach is a combination of all the three above, it focuses on the process of writing, taking account knowledge of social context and purposes of text in genre writing and observes features of texts as in product-based approach. (Rhalmi 2018). Currently, process writing is given much emphasizes in ESL classrooms. It helps students to produce and kinds of writing by employing the four steps. Besides employing these approaches, teachers also employ different types of strategies to make the teaching and learning writing in second language classroom in fruitful. Some of the popular strategies "include modelling, shared writing, guided writing, and interactive writing". (Lan et al. 2011, p.148). This approach has its plus points, that is, it is more suitable to students in secondary schools. Its limitations are, it needs careful and tedious planning, it consumes a lot of time in planning and teaching.

\section{Process Product Approach}

Process product approach combines product approach and process approach. Employing this approach is to develop students writing skills by mastering product approach prior to process approach. Students need to master writing mechanics and get familiar with sample texts or model essays at this stage and proceed with process writing, which is developing writing employing all the stages in process writing stages namely, prewriting, drafting, revising, editing and publishing to compose a own generated story. This approach's main disadvantages are linked to its complexity and the time and cost engaged in achieving it. (Carta 1987).

\section{Past Studies}

There are a number of studies that discuss the best approach for second language teachers to adopt, particularly in ESL classrooms. Nordin 2017 in his study on tertiary students reported that there is no one particular approach fits the ESL students in fact process and genre approach complements each other in teaching the writing skills.

In another study, Watson (1982) has reported that, models or product-based approach is widely opted in ESL classroom. Yet, he believes that, product-based approach alone does not help students in writing but this product based approached should be integrated with process-based approach to produce a good writer.

A study done by Hassan and Akhand (2010) in analyzing the impact on learners ' quality of the product and process approach to learning reported that the tertiary students performed better in writing by combining product and process approach. The blending approach developed their writing skills. 
Most of the studies examines the two main popular approaches in teaching writing namely product-based approach and process-based approach. However, there are other relevant approaches such as genre-based approaches, combination genre process and product process approaches which contributes to improve ESL students writing skills. Thus, only a little known in outcomes of blended approaches in teaching writing.

\section{Methodology}

The method adopted conduct the systematic review is based on five steps proposed by Khan et al. (2003, p.118). According to them, the five steps are "framing questions for a review, identifying relevant studies, assessing the quality of studies, summarizing the evidence and interpreting the findings". The first stage of the procedure is framing research questions for the review. Therefore, problems should be identified carefully and clear. The questions should be well structured to avoid any ambiguity. A good research questions will lead to a good research process. Once the questions are identified, other changes such as identifying the population and research designs are identifies. In this case, ESL learners in all levels, from primary to tertiary education level are chosen. The next step is identifying relevant studies, where studies related to the objectives set, we searched. I decided the use the online materials from well-known databases, such as JSTOR, Google Scholar, Science Direct, Springer e-Journals and Educational Resources Information Centre or better known as ERIC, SAGE, Scientific Research Publishing and Scopus were downloaded and read extensively prior to analyzing them. Boolean Operators was used to connect and define the search terms relationship based on the objectives set. The third step is assessing the quality of the studies where a step by step review was done. I have rechecked the research questions and the objectives are relevant to each other and to the journals and the articles chosen. The fourth step is summarizing the evidence collected and tabulated using statistical method to interpret the data and supported with graphics for better comprehension use. Finally, the study was summarized with recommendations. 
INTERNATIONAL JOURNAL OF ACADEMIC RESEARCH IN PROGRESSIVE EDUCATION AND DEVELOPMENT

Vol. 8, No. 4, 2019, E-ISSN: 2226-6348 @ 2019 HRMARS

\section{Findings and Discussion}

Total of 15 studies based on the writing approaches from the year 2000 to 2019 were chosen for the systematic review and the findings as

\begin{tabular}{|c|c|c|c|c|c|c|c|}
\hline & Study & $\begin{array}{c}\text { No of } \\
\text { Participan } \\
\text { ts }\end{array}$ & $\begin{array}{l}\text { Research } \\
\text { Design }\end{array}$ & $\begin{array}{c}\text { Types of } \\
\text { interventio } \\
n\end{array}$ & $\begin{array}{l}\text { Approac } \\
\mathrm{h} \\
\text { adopted }\end{array}$ & $\begin{array}{c}\text { Total } \\
\text { interve } \\
\text { ntion } \\
\text { duratio } \\
\text { n }\end{array}$ & Results \\
\hline 1 & $\begin{array}{l}\text { Purnawar } \\
\text { man, } \\
\text { Susilawati } \\
\& \\
\text { Sundayan } \\
\text { a } \\
(2015)\end{array}$ & $\begin{array}{l}17 \\
\text { eleventh } \\
\text { grade } \\
\text { students } \\
\text { from } \\
\text { senior } \\
\text { high } \\
\text { school }\end{array}$ & $\begin{array}{l}\text { Qualitative } \\
\text { Case study }\end{array}$ & $\begin{array}{l}\text { Blended } \\
\text { learning } \\
\text { using } \\
\text { Edmodo in } \\
\text { writing }\end{array}$ & Genre & $\begin{array}{l}1 \\
\text { month }\end{array}$ & $\begin{array}{l}\text { - Genre } \\
\text { based } \\
\text { approached } \\
\text { can be } \\
\text { taught } \\
\text { using } \\
\text { Edmodo } \\
\text { Edmodo } \\
\text { facilitates } \\
\text { the } \\
\text { students' } \\
\text { engagemen } \\
\text { t in the } \\
\text { teaching } \\
\text { cognitively } \\
\text { through } \\
\text { Note menu. }\end{array}$ \\
\hline 2 & $\begin{array}{l}\text { Karimah, } \\
\text { Setyona \& } \\
\text { Sukmaant } \\
\text { ara } \\
(2017)\end{array}$ & $\begin{array}{l}8^{\text {th }} \text { grade } \\
\text { students } \\
\text { (purposive } \\
\text { sampling } \\
\text { method) } \\
120 \\
\text { students }\end{array}$ & $\begin{array}{l}\text { Action } \\
\text { Research }\end{array}$ & $\begin{array}{l}\text { the learners } \\
\text { showed } \\
\text { different } \\
\text { reactions } \\
\text { based on } \\
\text { the Uses } \\
\text { and } \\
\text { Gratificatio } \\
\mathrm{n} \text { Theory } \\
\text { (UGT) } \\
\text { framework } \\
\text { to the use } \\
\text { of Edmodo. }\end{array}$ & Genre & $\begin{array}{l}3 \\
\text { meetin } \\
\text { gs of } 80 \\
\text { minute } \\
\text { s }\end{array}$ & $\begin{array}{l}\text { Blended } \\
\text { learning } \\
\text { using } \\
\text { Edmodo in } \\
\text { writing, } \\
\text { students } \\
\text { showed } \\
\text { independen } \\
\text { ce in writing } \\
\text { a personal } \\
\text { recount text }\end{array}$ \\
\hline 3 & $\begin{array}{l}\text { Gutiérrez, } \\
\text { Puello \& } \\
\text { Galvis } \\
\text { (2015) }\end{array}$ & $\begin{array}{l}20 \\
\text { participan } \\
\text { ts from }\end{array}$ & $\begin{array}{l}\text { Action } \\
\text { research } \\
\text { experiment } \\
\text { al }\end{array}$ & $\begin{array}{l}\text { Using } \\
\text { pictures } \\
\text { series to } \\
\text { enhance }\end{array}$ & $\begin{array}{l}\text { Process } \\
\text { based } \\
\text { approac } \\
\text { h,produc }\end{array}$ & $\begin{array}{l}16 \\
\text { weeks }\end{array}$ & $\begin{array}{l}\text { - The } \\
\text { experimenta } \\
\text { I group } \\
\text { which }\end{array}$ \\
\hline
\end{tabular}


INTERNATIONAL JOURNAL OF ACADEMIC RESEARCH IN PROGRESSIVE EDUCATION AND DEVELOPMENT

Vol. 8, No. 4, 2019, E-ISSN: 2226-6348 @ 2019 HRMARS

\begin{tabular}{|c|c|c|c|c|c|c|c|}
\hline & & $\begin{array}{l}\text { ninth } \\
\text { grade }\end{array}$ & & $\begin{array}{l}\text { narrative } \\
\text { writing }\end{array}$ & $\begin{array}{l}\text { t-based } \\
\text { approac } \\
\text { h }\end{array}$ & & $\begin{array}{l}\text { employ } \\
\text { process- } \\
\text { based } \\
\text { approach } \\
\text { performed } \\
\text { better }\end{array}$ \\
\hline 4 & $\begin{array}{l}\text { Jones } \\
(2006)\end{array}$ & $\begin{array}{l}18 \text { college } \\
\text { students } \\
5 \text { males } 13 \\
\text { female }\end{array}$ & $\begin{array}{l}\text { Qualitative } \\
\text { Case study }\end{array}$ & $\begin{array}{l}\text { Use of } \\
\text { Weblogs as } \\
\text { a } \\
\text { pedagogical } \\
\text { tool for the } \\
\text { writing } \\
\text { process } \\
\text { Approach }\end{array}$ & $\begin{array}{l}\text { Process } \\
\text { based } \\
\text { approac } \\
\text { h }\end{array}$ & & $\begin{array}{l}\text { - Blogging } \\
\text { has been } \\
\text { shown to be } \\
\text { an efficient } \\
\text { writing } \\
\text { instrument } \\
\text { - Process } \\
\text { based } \\
\text { approach } \\
\text { facilitated } \\
\text { and } \\
\text { students } \\
\text { were aware } \\
\text { for writing; } \\
\text { students } \\
\text { motivated } \\
\text { to writing }\end{array}$ \\
\hline 5 & $\begin{array}{l}\text { Wei } \\
\text { (2016) }\end{array}$ & $\begin{array}{l}19 \\
\text { students } \\
\text { from the } \\
\text { first year } \\
\text { Bachelor } \\
\text { of } \\
\text { Teaching } \\
\text { (TESL) } \\
\text { degree } \\
\text { programm } \\
\text { e }\end{array}$ & $\begin{array}{l}\text { Exploratory } \\
\text { case study }\end{array}$ & $\begin{array}{l}\text { use of } \\
\text { genre- } \\
\text { based } \\
\text { writing } \\
\text { instruction } \\
\text { to acquire } \\
\text { the genre } \\
\text { conventions } \\
\text { of writing a } \\
\text { literary } \\
\text { criticism }\end{array}$ & $\begin{array}{l}\text { Genre } \\
\text { approac } \\
\text { h }\end{array}$ & $\begin{array}{l}\text { Two } \\
\text { months }\end{array}$ & $\begin{array}{l}\text { - improved } \\
\text { their ability } \\
\text { to } \\
\text { demonstrat } \\
\text { e all the } \\
\text { rhetorical } \\
\text { and } \\
\text { linguistic } \\
\text { conventions } \\
\text { of a literary } \\
\text { criticism. }\end{array}$ \\
\hline 6 & $\begin{array}{l}\text { Yomana } \\
\text { Christina } \\
\text { Jothi } \\
\text { Shamini \& } \\
\text { Md Yunus } \\
\text { (2019) }\end{array}$ & $\begin{array}{l}55 \\
\text { Secondary } \\
\text { Four } \\
\text { pupils }\end{array}$ & $\begin{array}{l}\text { action } \\
\text { research }\end{array}$ & $\begin{array}{l}\text {-Use hi-five } \\
\text { Fingers and } \\
\text { Snack Bars } \\
\text { in their } \\
\text { writing } \\
\text { through } \\
\text { social } \\
\text { media }\end{array}$ & $\begin{array}{l}\text { Product } \\
\text { and } \\
\text { Process- } \\
\text { based }\end{array}$ & $\begin{array}{l}\text { three } \\
\text { months } \\
\text {. }\end{array}$ & $\begin{array}{l}\text { - there is an } \\
\text { improveme } \\
\text { nt in } \\
\text { pupils' } \\
\text { grades in } \\
\text { their } \\
\text { writing } \\
\text { performanc }\end{array}$ \\
\hline
\end{tabular}




\begin{tabular}{|c|c|c|c|c|c|c|c|}
\hline & & & & $\begin{array}{l}\text { (Powtoon \& } \\
\text { Facebook). }\end{array}$ & & & $\begin{array}{l}\text { e after Use } \\
\text { hi-five } \\
\text { fingers and } \\
\text { snack bars } \\
\text { through } \\
\text { social media }\end{array}$ \\
\hline 7 & $\begin{array}{l}\text { Barrot } \\
(2016)\end{array}$ & $\begin{array}{l}171 \text { first } \\
\text { year } \\
\text { university } \\
\text { students }\end{array}$ & $\begin{array}{l}\text { Self-report } \\
\text { method }\end{array}$ & $\begin{array}{l}\text { Influence of } \\
\text { the } \\
\text { Facebook e- } \\
\text { portfolio on } \\
\text { writing } \\
\text { methods of } \\
\text { ESL } \\
\text { students }\end{array}$ & $\begin{array}{l}\text { Process } \\
\text { genre } \\
\text { approac } \\
\text { h }\end{array}$ & $\begin{array}{l}14 \\
\text { weeks }\end{array}$ & $\begin{array}{l}\text { The e- } \\
\text { portfolio } \\
\text { based on } \\
\text { Facebook } \\
\text { had a } \\
\text { beneficial } \\
\text { effect on } \\
\text { the writing } \\
\text { practices of } \\
\text { learners. } \\
\text { Students } \\
\text { saw } \\
\text { Facebook } \\
\text { as a } \\
\text { feasible } \\
\text { instrument } \\
\text { for } \\
\text { evaluating } \\
\text { the e- } \\
\text { portfolio. }\end{array}$ \\
\hline 8 & $\begin{array}{l}\text { Faraj } \\
(2015)\end{array}$ & $\begin{array}{l}\text { thirty } \\
\text { second- } \\
\text { year } \\
\text { college } \\
\text { students }\end{array}$ & $\begin{array}{l}\text { Experiment } \\
\text { al } \\
\text { Research } \\
\text { One group } \\
\text { (pre post } \\
\text { test) }\end{array}$ & $\begin{array}{l}\text { Scaffolding } \\
\text { writing } \\
\text { process }\end{array}$ & $\begin{array}{l}\text { Process } \\
\text { approac } \\
\mathrm{h}\end{array}$ & - & $\begin{array}{l}\text { - Test } \\
\text { showed } \\
\text { improveme } \\
\text { nt in control } \\
\text { group result }\end{array}$ \\
\hline 9 & $\begin{array}{l}\text { Alshahrani } \\
\& \\
\text { Windeatt } \\
\text { (2019) }\end{array}$ & $\begin{array}{l}\text { 46particip } \\
\text { ants in ESL } \\
\text { English } \\
\text { Centre. }\end{array}$ & $\begin{array}{l}\text { Experiment } \\
\text { research } \\
\text { design } \\
\text { (Control } \\
\text { group and } \\
\text { experiment } \\
\text { al group) }\end{array}$ & $\begin{array}{l}\text { Use of an e- } \\
\text { portfolio } \\
\text { structure to } \\
\text { enhance } \\
\text { academic } \\
\text { writing } \\
\text { efficiency of } \\
\text { ESL } \\
\text { students }\end{array}$ & $\begin{array}{l}\text { Process } \\
\text { approac } \\
\text { h }\end{array}$ & & $\begin{array}{l}\text { e-portfolio } \\
\text { software, } \\
\text { facilitates } \\
\text { writing. } \\
\text { - Frequent } \\
\text { peer and } \\
\text { teacher } \\
\text { written } \\
\text { feedback } \\
\text { promote }\end{array}$ \\
\hline
\end{tabular}




\begin{tabular}{|c|c|c|c|c|c|c|c|}
\hline & & & & & & & $\begin{array}{l}\text { learners to } \\
\text { write. } \\
\text { A } \\
\text { substantial } \\
\text { improveme } \\
\text { nt in the } \\
\text { teaching } \\
\text { and reading } \\
\text { performanc } \\
\text { e of ESL } \\
\text { students } \\
\text { was } \\
\text { discovered }\end{array}$ \\
\hline 10 & $\begin{array}{l}\text { Sapkota } \\
(2012)\end{array}$ & $\begin{array}{l}\text { ten } \\
\text { students } \\
\text { from a B. } \\
\text { Ed } \\
\text { College. }\end{array}$ & $\begin{array}{l}\text { Action } \\
\text { research } \\
\text { pre-test, } \\
\text { progressive } \\
\text { test and } \\
\text { post-tests }\end{array}$ & $\begin{array}{l}\text { Developing } \\
\text { students } \\
\text { process } \\
\text { writing skills } \\
\text { through } \\
\text { peer and } \\
\text { teacher } \\
\text { correction }\end{array}$ & $\begin{array}{l}\text { Process } \\
\text { approac } \\
\text { h }\end{array}$ & $\begin{array}{l}\text { Four } \\
\text { weeks }\end{array}$ & $\begin{array}{l}\text { An increase in } \\
\text { students' level } \\
\text { of proficiency } \\
\text { in the use of } \\
\text { grammatical } \\
\text { units and in } \\
\text { using } \\
\text { mechanics of } \\
\text { writing } \\
\text { Effective use } \\
\text { of peer } \\
\text { correction } \\
\text { followed by } \\
\text { teacher } \\
\text { correction. }\end{array}$ \\
\hline 11 & $\begin{array}{l}\text { Pratama } \\
(2015)\end{array}$ & 7th grade & $\begin{array}{l}\text { action } \\
\text { research } \\
\text { with } \\
\text { qualitative } \\
\text { approach }\end{array}$ & $\begin{array}{l}\text { Mind } \\
\text { mapping } \\
\text { technique } \\
\text { to improve } \\
\text { writing skills }\end{array}$ & $\begin{array}{l}\text { Process } \\
\text { approac } \\
\text { h }\end{array}$ & $\begin{array}{l}\text { Two } \\
\text { cycles } \\
\text { with } \\
\text { two } \\
\text { meetin } \\
\text { gs each }\end{array}$ & $\begin{array}{l}\text { - Mind } \\
\text { mapping } \\
\text { skills are } \\
\text { improved } \\
\text { separately or } \\
\text { classically }\end{array}$ \\
\hline 12 & $\begin{array}{l}\text { Handayani } \\
\text { \& Siregar } \\
\text { (2013) }\end{array}$ & $\begin{array}{l}37 \\
\text { students } \\
\text { Of senior } \\
\text { high } \\
\text { school }\end{array}$ & $\begin{array}{l}\text { action } \\
\text { research } \\
\text { with } \\
\text { qualitative } \\
\text { approach }\end{array}$ & $\begin{array}{l}\text { Application } \\
\text { of the } \\
\text { process } \\
\text { genre } \\
\text { strategy in } \\
\text { descriptive } \\
\text { text } \\
\text { learning }\end{array}$ & $\begin{array}{l}\text { Process } \\
\text { genre } \\
\text { approac } \\
\text { h }\end{array}$ & $\begin{array}{l}\text { Two } \\
\text { cycles } \\
\text { on } 10 \\
\text { meetin } \\
\text { gs }\end{array}$ & $\begin{array}{l}\text { Process } \\
\text { Genre } \\
\text { Approach } \\
\text { teaching } \\
\text { writing } \\
\text { increases } \\
\text { the writing } \\
\text { competency } \\
\text { of learners }\end{array}$ \\
\hline
\end{tabular}




\begin{tabular}{|c|c|c|c|c|c|c|c|}
\hline & & & & & & & $\begin{array}{l}\text { Improved } \\
\text { the } \\
\text { motivation } \\
\text { of learners } \\
\text { to learn } \\
\text { writing } \\
\text { Developed } \\
\text { the ability } \\
\text { of learners } \\
\text { to express } \\
\text { their } \\
\text { thoughts } \\
\text { more in } \\
\text { order to } \\
\text { support the } \\
\text { job of } \\
\text { writing }\end{array}$ \\
\hline 13 & $\begin{array}{l}\text { Ahn } \\
(2012)\end{array}$ & $\begin{array}{l}\text { L2 primary } \\
\text { school } \\
\text { students. } \\
\text { (Year } 5 \\
\text { and 6) }\end{array}$ & $\begin{array}{l}\text { Action } \\
\text { research }\end{array}$ & $\begin{array}{l}\text { Implementi } \\
\text { ng a genre } \\
\text { strategy to } \\
\text { developing } \\
\text { main school } \\
\text { students ' } \\
\text { writing skills } \\
\text { through } \\
\text { scaffolding } \\
\text { in grades } 5 \\
\text { and } 6 \text { L2 }\end{array}$ & $\begin{array}{l}\text { Genre } \\
\text { based }\end{array}$ & $\begin{array}{l}\text { 10- } \\
\text { weeks } \\
\text { (two } \\
\text { lessons } \\
\text { per } \\
\text { week) }\end{array}$ & $\begin{array}{l}\text { - The active } \\
\text { scaffolding } \\
\text { processes of } \\
\text { teachers at } \\
\text { the early } \\
\text { stage of the } \\
\text { cycle } \\
\text { benefited } \\
\text { students by } \\
\text { making them } \\
\text { aware of the } \\
\text { different } \\
\text { ways in which } \\
\text { texts are } \\
\text { organized for } \\
\text { different } \\
\text { purposes of } \\
\text { communicati } \\
\text { on. } \\
\text { Increased } \\
\text { confidence } \\
\text { among } \\
\text { students and } \\
\text { prompted a } \\
\text { favourable }\end{array}$ \\
\hline
\end{tabular}


INTERNATIONAL JOURNAL OF ACADEMIC RESEARCH IN PROGRESSIVE EDUCATION AND DEVELOPMENT

Vol. 8, No. 4, 2019, E-ISSN: 2226-6348 @ 2019 HRMARS

\begin{tabular}{|c|c|c|c|c|c|c|c|}
\hline & & & & & & & $\begin{array}{l}\text { attitude to } \\
\text { writing }\end{array}$ \\
\hline 14 & $\begin{array}{l}\text { Pasand } \\
\text { \& Haghi } \\
\text { (2013) }\end{array}$ & $\begin{array}{l}\text { twelve } \\
\text { intermedi } \\
\text { ate EFL } \\
\text { learners, } \\
\text { between } \\
13 \text { to } 15 \\
\text { years old }\end{array}$ & $\begin{array}{l}\text { quasi- } \\
\text { experiment } \\
\text { al design }\end{array}$ & $\begin{array}{l}\text { Scaffolding } \\
\text { thorough } \\
\text { model } \\
\text { essays }\end{array}$ & $\begin{array}{l}\text { Process- } \\
\text { Product } \\
\text { Approac } \\
\text { h }\end{array}$ & $\begin{array}{l}\text { two- } \\
\text { session } \\
\text { writing } \\
\text { class }\end{array}$ & $\begin{array}{l}\text { - Completing } \\
\text { the model } \\
\text { text in the } \\
\text { writing of } \\
\text { process } \\
\text { products has } \\
\text { a beneficial } \\
\text { impact on } \\
\text { certain } \\
\text { elements of } \\
\text { their } \\
\text { precision in } \\
\text { writing } \\
\text { mechanics, } \\
\text { syntax and } \\
\text { coherence } \\
\text { students' } \\
\text { writing } \\
\text { accuracy } \\
\text { increased } \\
\text { through } \\
\text { model text }\end{array}$ \\
\hline 15 & $\begin{array}{l}\text { Mehr } \\
(2016)\end{array}$ & $\begin{array}{l}60 \text { Iranian } \\
\text { learners } \\
42 \\
\text { females } \\
\text { and } 18 \\
\text { males }\end{array}$ & $\begin{array}{l}\text { quasi- } \\
\text { experiment } \\
\text { al research }\end{array}$ & $\begin{array}{l}\text { Instructions } \\
\text { based on } \\
\text { product and } \\
\text { process } \\
\text { approach }\end{array}$ & $\begin{array}{l}\text { process } \\
\text { and } \\
\text { product }\end{array}$ & $\begin{array}{l}12 \\
\text { session } \\
\mathrm{s}\end{array}$ & $\begin{array}{l}\text { - Process } \\
\text { approach } \\
\text { that has a } \\
\text { huge impact } \\
\text { on the } \\
\text { writing } \\
\text { performance } \\
\text { of EFL } \\
\text { students } \\
\text { Positive } \\
\text { impact of the } \\
\text { process } \\
\text { approach on } \\
\text { the writing } \\
\text { skills } \\
\text { behaviour of } \\
\text { EFL students } \\
\text { improved } \\
\text { - }\end{array}$ \\
\hline
\end{tabular}


INTERNATIONAL JOURNAL OF ACADEMIC RESEARCH IN PROGRESSIVE EDUCATION AND DEVELOPMENT

Vol. 8, No. 4, 2019, E-ISSN: 2226-6348 @ 2019 HRMARS

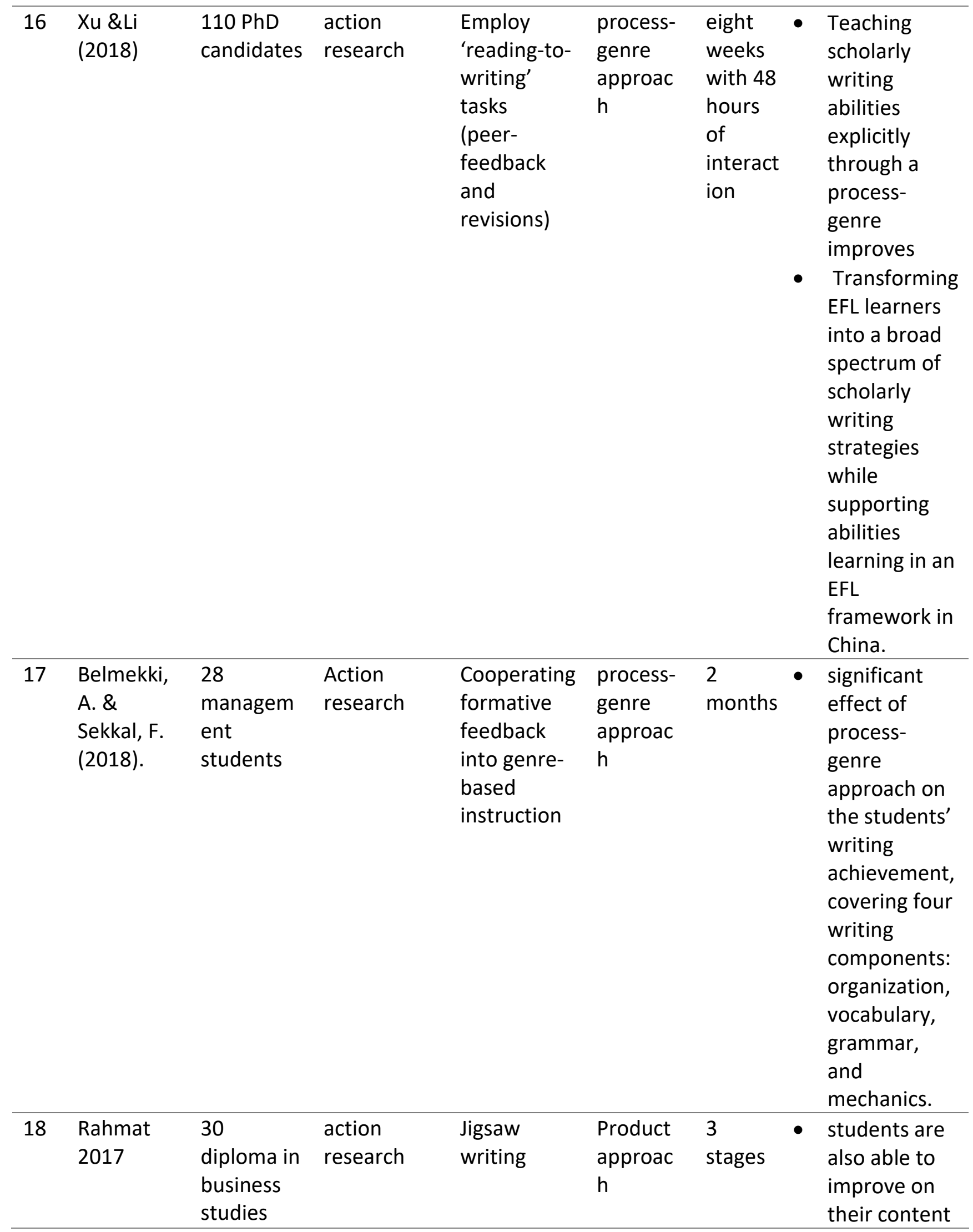




\begin{tabular}{ll}
\hline students & skills, as well \\
females & as \\
and 12 & communicati \\
males & ve strategies \\
& as a result of \\
& the \\
& interaction \\
& participants \\
& enjoyed the \\
& jigsaw \\
& activity and \\
& found that \\
& the \\
& cooperative \\
& learning \\
& helped save \\
& time \\
& jigsaw writing \\
& activities \\
& allowed them \\
& to share \\
& ideas
\end{tabular}

Table 1 : Summary of past related studies in employing writing approaches in ESL context In total of 18 past related studies were identified using 5 different approaches highlighted. The studies are from different level of ESL classrooms, tertiary to primary school level. Four studies employed genre-based approach in the researches. The finding of their studies showed a significant improvement in employing this approach. Purnawarman, Susilawati and Sundayana (2015) employing Edmodo writing instructions in a blended learning environment in a senior high school, noticed Edmodo facilitates the students' engagement in the teaching cognitively through Note menu. Meanwhile Karimah, Setyona and Sukmaantara (2017), in their study over 8th grade students, employing genre-based approach in teaching writing found that the learners showed different reactions when the framework on the Uses and Gratification Theory (UGT) employed in the use of Edmodo. In addition, using Edmodo in writing, students showed independence in writing a personal recount text.

In another case study, Wei (2016) over 19 students from the first year Bachelor of Teaching (TESL) degree programme where the use of genre-based writing instruction to acquire the genre conventions of writing a literary criticism improved their ability to demonstrate all the rhetorical and linguistic conventions of a literary criticism. Ahn (2012) on his study conducted in on elementary school students. Teaching writing using genre approach in order to develop writing ability of Year 5 and 6 L2 elementary students through scaffolding found the active scaffolding processes of teachers at the early stage of the cycle benefited students by making them aware of the different ways in which texts are organized for different purposes of communication. Moreover, this strategy has resulted on increment of self confidence among the participants. 
Another five studies analysed are studies which employed process-based approach writing. Jones (2006) in his case study on 18 college students in Using Weblogs as a teaching instrument for writing demonstrated that blogging is an efficient instrument for writing. In addition, processbased approach facilitated and the students were aware the purpose for writing. The finding also indicated that students were motivated to write. In a similar process-based approach in writing research, Faraj (2015), on her research on thirty second-year college students which employed experimental research in scaffolding writing process showed improvement in control group result in her post results. Meanwhile Alshahrani and Windeatt (2019) performed an experimental research in use of an e-portfolio structure to enhance academic writing efficiency of ESL students. The results showed e-portfolio software, facilitates writing. In addition, frequent peer and teacher written feedback promote learners to write. Other than that, a substantial improvement in the teaching and reading performance of ESL students were also discovered.

In another study by Sapkota (2012), involving ten college students to developing students process writing skills through peer and teacher correction noticed, an increase in student skills in the use of grammar units and the use of writing mechanics in four weeks. The use of peer correction accompanied by teacher correction was discovered to be efficient in writing processes for learners. The fifth study was done by Pratama (2015), towards 7th grade students. A qualitative approach was employed in using Mind mapping technique to improve writing skills. The findings showed that writing skill with Mind mapping skills improved separately or classically.

In employing process genre approach in the research, there were four researches identified. Barrot (2016) in his research on 171 students in the first year of the university a self-report method on Influence of the Facebook e-portfolio on writing methods of ESL students using process genre approach reported his finding which showed The e-portfolio based on Facebook had a beneficial effect on the writing practices of learners students saw Facebook as a feasible instrument for evaluating the e-portfolio. Meanwhile, Belmekki and Sekkal, (2018), did a study on 28 management students in cooperating formative feedback into process genre-based instruction noticed a significant effect of process-genre approach on the students' writing achievement, covering four writing components: organization, vocabulary, grammar, and mechanics in 2 months. Xu and Li (2018) in his research in employing 'reading-to-writing' tasks (peer-feedback and revisions) towards PhD candidates found that in eight weeks with 48 hours of interaction the teaching scholarly writing abilities explicitly through a process-genre improves. In addition, the result is seen to transform EFL learners into a broad spectrum of scholarly writing strategies while supporting abilities learning in an EFL framework in China. Handayani and Siregar (2013), found that 37 students of senior high school teaching writing using Process Genre Approach teaching writing increases the writing competency of learners. In addition, improved the motivation of learners to learn writing and developed the ability of learners to express their thoughts more in order to support the job of writing it improved students' motivation in learning writing and developed students' skill to communicate their ideas more to support the purpose of writing task.

Another writing approach which popularly employed in ESL writing is, process product approach. Mehr (2016), in his research towards 60 Iranian learners employed a quasi-experimental research to measure the effectiveness of process - product approach instructions based in EFL classroom 
found that Process approach that has a huge impact on the writing performance of the students. In another study in scaffolding ESL writing thorough model essays, Pasand and Haghi (2013) reported that twelve intermediate EFL learners, between 13 to 15 years old, process-product Writing has a favourable impact on certain elements of their writing precision, such as punctuation, capitalization, spelling, subject-verb agreement, tension, the use of connectors, the use of right pronouns and possessives and the use of model text.

In an action research conducted by Yomana Christina Jothi Shamini and Melor (2019)reported 55 participants of Secondary Four pupils in employing process product in using the hi-five Fingers and Snack Bars via social media (Powtoon and Facebook) in their writing in three months, there was an improvement of the writing achievement of students after using hi-five fingers and snack bars through social media. In an experimental study by Gutiérrez, Puello and Galvis (2015) 20 participants from ninth grader reported the experimental group which employ process-based approach performed better using pictures series to enhance narrative writing.

Product based approach is not very popular and only one study could be identified in the range from year 2000 to 2019.The study was carried out by Noor Hanim (2017) to 30 Diploma in business studies students. The study is in employing product-based approach in Jigsaw writing in writing business letter. The jigsaw writing enables students to write short sentences in a group as jigsaw writing a cooperative learning strategy. The researcher stated students improved on their content skills, as well as communicative strategies as a result of the interaction and participants enjoyed the jigsaw activity and found that the cooperative learning helped save time. In addition, the jigsaw writing activities allowed them to share ideas.

\section{Conclusion}

A total of 18 studies were identified in this systematic review analysis in identifying writing approaches employed in the period of 19 years. The studies are based on all the levels, from primary to tertiary level in ESL context instructions. There are four studies for the category of genre based, process genre based and process product based. There are 5 studies on processbased approach and one study from product-based approach. All the approaches employed in the researches has its advantages and disadvantages yet a good and proper selection of approaches based in the students need is vital to make the students writing successful. Moreover, enough time should be given to students to get used to a certain approach. In addition, scaffolding is crucial in assisting the students in each and every step of learning to write. One way to scaffold students is by giving feedback. Teachers need to give feedback to students' writing so that that they learn from mistakes.

Scaffolding is important to retain the students' interest in the classroom, anxiety in writing arise when students fail to compose. Hence, students' interest towards writing will dampen and gradually they lose interest in writing. Thus, scaffolding will lower their anxiety in writing. Feedback from peer is important as students will be more comfortable when corrected by peer. Other strategies, such as employing ICT and Web 2.0 application will engage students better. Hence, knowing students, selecting appropriate writing approaches, and scaffolding in ESL classroom is vital to make students improve in their writing. The limitation of this systematic review is, the approaches are only based on popular approaches in ESL writing classroom. There are other approaches such as free writing, paragraph pattern approaches, grammar syntax 
organization approaches and communicative approach. Next, this study did not incorporate other data from systematic reviews, it is solely on single researches. For future systematic review others researchers may include, other approaches and also analyze other systematic reviews on writing approaches.

\section{What Approach should ESL Teachers Employ in their Teaching of Writing}

The outcomes from the above finding it can be concluded that, ESL teachers are is best to employ Process based approach, especially in teaching of secondary level and tertiary level education. Undoubtedly true, adult students are more independent and they possess sufficient knowledge in content and their language mastery is greater than the younger ESL learner as they are novice writers. Due, to these advantages possessed by adult learners, it will be undemanding for these learners to employ the writing process systematically. Finding supports these ideas, as most of the studies selected process-based approach studies which are done towards university participants. Thus, to scaffold the teaching of writing in higher education level, process writing will be the best approach. Meanwhile, in secondary and primary school level, process-product approach and process-genre approach will be suitable to be employed in the ESL classrooms, as scaffolding is given importance when selecting these approaches. Younger students need scaffolding in order to produce a good writing. To low achievers in ESL classrooms, product process based is best. Students learns writing process based on the model text and may produce a similar text by employing techniques in process writing as drafting, revising, editing and publishing. Other than that, when employing product process approach, low achievers and elementary students can improve their writing mechanics which is an important element in any writing. On the hand, genre-based writing is also popular at tertiary level due to different genre of writing is a requirement in tertiary level. For instance, in documentation, reporting and letter writing. Hence, to improve students writing skills in tertiary level, genre-based writing would be good choice. Last but not least, even though product-based approach is not widely employed in this period (2000-2019), it is still relevant in teaching weak students at primary school level.

\section{How Writing Instructions should be Planned in ESL Classroom}

I) Knowing the Students.

It is important for the teachers in ESL classrooms to know their students' level well before selecting the best writing approach in the classroom. Students with average proficiency level may employ process or process genre and process product approach. With some scaffolding and teacher's and peer review, writing can be improved. Meanwhile, very weak students as mentioned before may employ product-based approach so that students imitate the model and familiarize with the model and produce almost similar text with some scaffoldings. The studies above show the selection of approaches was accurate hence a positive outcome is seen.

li) Knowing the Methodology

Employing an approach correctly is crucial in teaching writing to ESL students is vital to see an improvement and better result in writing. This can be viewed in the above studies when researchers, clearly described the methods in each research. Without a proper planning, the objectives cannot be achieved. As ESL teachers, it is essential to be familiar with each approach to teaching writing before deciding which to choose to teach writing to their students. Hence, 
planning the lesson with suitable approach, material selection based on the students need is crucial in order to achieve successful.

iii) Scaffolding

In most of the researches, scaffolding has its important role in motivation students to write. Teachers should incorporate scaffolding in the writing lessons to help the students regardless of their level of proficiency. Scaffolding during the lesson or by giving feedback during the writing process is vital. Peer reviews are also important to scaffold in writing classroom.

\section{Recommendations}

1. Teachers should combine the teaching writing approaches to scaffold students writing as every approach has its shortcomings.

2. A further research should be done in other approaches in teaching writing so that teachers in ESL classrooms have wider options to utilize in the ESL writing classrooms.

3. In the further researches done should be focused more on young or novice writers as teaching writing using various approaches will produce a better writer from young age.

In a nutshell, teacher play a crucial role in teaching writing skills. Besides having a content knowledge, employing the right pedagogical approaches in teaching writing is necessary based on the needs and levels of their students.

\section{References}

Ahn, H. (2012) Teaching writing skills based on a genre approach to 12 primary school students: An action research. English Language Teaching 5(2):2-16.

Aziz, H. (2018). Miles to go in English Proficiency. New Straits Times.10 August: BI

Badger, R. \& White G. (2000). A process genre approach to teaching writing. ELT Journal, 54(2): 153-160.

Bandura, A. (1993). Perceived self-efficacy in cognitive development and functioning. Educational psychologist. 28(2): 117-148.

Bandura,A. (2001). Social cognitive theory: An agentic perspective. Annual Review of Psychology 52(1):1-26.

Barrot, J. S. (2016). Using Facebook-based e-portfolio in ESL writing classrooms: Impact and challenges. Language, Culture and Curriculum, 29(3):286-301.

Belmekki, A., \& Sekkal, F. (2018) The effect of process-genre approach on ESL students' achievement in writing business letters. European Journal of Research and Reflection in Educational Sciences. 6(2).

Carta, J. J., \& Greenwood, C. R. (1987). Process-product analysis: An approach for studying critical variables in early intervention. Journal of the Division for Early Childhood 12(1):85-91.

Cooper, M. M. (1986). The ecology of writing. College English, 48(4), 364-375. 
Elashri, E. A. E., \& Ibrahim, I. (2013). The effect of the genre-based approach to teaching writing on The EFL Al-Azhr secondary students' writing skills and their attitudes towards writing. Online Submission.

Faraj, A. K. A. (2015). Scaffolding EFL students' writing through the writing process approach. Journal of Education and Practice.6 (13): 131-141.

Flower, L., \& Hayes, J. R. (1981). A cognitive process theory of writing. College composition and communication, 32(4), 365-387.

Ghabool, N. Marianne Mariadass, Sayyed Hossien Kashef (2012). Investigating Malaysian ESL students' writing problems on conventions, punctuation, and language use at secondary school level. Journal of Studies in Education. 2(3):130-143.

Gutiérrez, K. G. C., Puello, M. N., \& Galvis L. A. P. (2015). Using pictures series technique to enhance narrative writing among ninth grade students at Institución Educativa Simón Araujo. English Language Teaching. 8(5): 45-71.

Harmer, J. (2004). How to teach writing. Harlow, UK: Pearson Education.

Handayani, S. W., \& Siregar, M. (2013). Improving students' writing achievement through the process genre approach. Register Journal of English Language Teaching of Fbs-Unimed. 2(2).

Hasan, M. K., \& Akhand, M. M. (2010). Approaches to writing in EFL/ESL context: Balancing product and process in writing class at tertiary level. Journal of NELTA, 15(1-2), 77-88.

Hodges, T. S. (2017). Theoretically speaking: An examination of four theories and how they support writing in the classroom. The Clearing House: A Journal of Educational Strategies, Issues and Ideas. 90(4): 139-146.

Hyland, K. (2015). Teaching and researching writing. London: Routledge

Karimah, H., Setyono, B., \& Sukmaantara, I. P.(2017). Implementing genre-based approach to promote students' recount text writing achievement at SMPN 1 Pujer Junior High School. EFL Education Journal. 4(3):957-974

Jusun, K. D. \& Yunus, M. (2017). The effectiveness of using sentence makers in improving writing performance among pupils in Lubok Antu rural schools. In International Conference on Education (ICE2) 2018: Education and Innovation in Science in the Digital Era :469-475.

Khan, K. S., Kunz, R., Kleijnen, J., \& Antes, G. (2003). Five steps to conducting a systematic review. Journal of The Royal Society of Medicine. 96 (3): 118-121.

Kroll, B. (Ed.). (1990). Second Language Writing: Research Insights for The Classroom. Cambridge: Cambridge University Press.

Lan, Y. F., Hung, C. L. \& Hsu, H. J. (2011). Effects of guided writing strategies on students' writing attitudes based on media richness theory. Turkish Online Journal of Educational Technology-TOJET.10(4): 148-164.

Lavelle, E., \& Zuercher, N. (2001). The writing approaches of university students. Higher education, 42(3): 373-391.

Lavelle, E., \& Bushrow, K. (2007). Writing approaches of graduate students. Educational Psychology.27(6): 807-822.

Maarof, N., Yamat, H., \& Li, K. L. (2011). Role of teacher, peer and teacher-peer feedback in enhancing ESL students' writing. World Applied Sciences Journal, 15(Innovation and Pedagogy for Lifelong Learning), 35-29. 
INTERNATIONAL JOURNAL OF ACADEMIC RESEARCH IN PROGRESSIVE EDUCATION AND DEVELOPMENT

Vol. 8, No. 4, 2019, E-ISSN: 2226-6348 @ 2019 HRMARS

Maghsoudi, M., \& Haririan, J. (2013). The impact of brainstorming strategies Iranian EFL learners' writing skill regarding their social class status. International Journal of language and Linguistics, 1(4-1), 60-67.

Mehr, H. S. (2017). The impact of product and process approach on iranian efl learners' writing ability and their attitudes toward writing skill. International Journal of English Linguistics. 7(2): 158-166.

Hasan, M. K., \& Akhand, M. M. (2010). Approaches to writing in EFL/ESL context: Balancing product and process in writing class at tertiary level. Journal of NELTA. 15(1-2):77-88.

Yunus, M. \& Chan, H. C. (2016). The use of mind mapping strategy in Malaysian University English Test (MUET) writing. Creative Education. 7(04): 619

Rhalmi, M. (2018). How to teach writing skills to ESL and EFL students.. https://www.myenglishpages.com/blog/how-to-teach-writing/

Normazidah Che Musa, Koo, Yew Lie and Hazita Azman.(2012). Exploring English language learning and teaching in Malaysia. GEMA: Online Journal of Language Studies. 12 (1): 3551.

Nordin, S. M. (2017). The best of two approaches: Process/genre-based approach to teaching writing. The English Teacher, 11.

Pasand, P. G., \& Haghi, E. B. (2013). Process-product approach to writing: The effect of model essays on EFL learners' writing accuracy. International Journal of Applied Linguistics and English Literature. 2(1): 75-79.

Purnawarman, P., Susilawati, S., \& Sundayana, W. (2016). The use of Edmodo in teaching writing in a blended learning setting. Indonesian Journal of Applied Linguistics. 5(2):242-252.

Rahmat, N. H. (2017). Exploring the Use Of Jigsaw Writing Among ESL Writers: A Classroom Research. Indonesian Efl Journal, 1(2), 123-134.

Ramasamy, R. M. M., \& Aziz, A. (2018). Peer Assessment in Writing Using Frog VLE in a Secondary School ESL Classroom. Creative Education. 9: 2265-2279.

Richards, J. C., \& Rodgers, T. S. (1986). Approaches and methods in language teaching. Cambridge University Press.

Scott, V. M. (1996). Rethinking foreign language writing. Heinle \& Heinle Publishers, 20 Park Plaza, Boston, MA 02116.

Steele, V. (2004). Product and process writing. http://www.englishonline.org.cn/en/teachers/ workshops/teaching-writing/teachingtips/ product-process [25th June. 2019]

Tangpermpoon, T. (2008). Integrated approaches to improve students writing skills for English major students. ABAC journal. 28(2).

Tuan, L. T. (2011). Teaching writing through genre-based approach. Theory \& Practice in Language Studies. 1(11).

Vygotsky L. S. (1978). Mind in Society: Development of Higher Psychological Processes.

Watson, C. B. (1982). The use and abuse of models in the ESL writing class. TESOL quarterly, 16(1), 5-14.

World Population Review. (2019).http://worldpopulationreview.com/countries/englishspeaking-countries/ 


\section{INTERNATIONAL JOURNAL OF ACADEMIC RESEARCH IN PROGRESSIVE EDUCATION AND}

DEVELOPMENT

Vol. 8, No. 4, 2019, E-ISSN: 2226-6348 ๑ 2019 HRMARS

Xu, X., \& Li, X. (2018). Teaching academic writing through a process-genre approach: A pedagogical exploration of an EAP Program in China. TESL-EJ. 22(2):2.

Yomana C., Christina Jothi P. Shamini P., Md. Yunus, M. (2019). Collaborative writing: an integration of snack bars and hi-five fingers via social media. Creative Education. 10: 475-484

Zhu, W. (2004). Faculty views on the importance of writing, the nature of academic writing, and teaching and responding to writing in the disciplines. Journal of Second Language Writing.13(1):29-48. 